\title{
Determining relevant traits for selecting landrace accessions of Phaseolus lunatus L. for insect resistance
}

\author{
Roberto Rafael Ruiz-Santiago ${ }^{1}$, Horacio Salomon Ballina-Gomez ${ }^{\text {Corresp., }}{ }^{2}$, Esau Ruiz-Sanchez ${ }^{3}$, Jaime Martinez- \\ Castillo $^{4}$, Rene Garruña-Hernandez ${ }^{5}$, Rubén Humberto Andueza-Noh ${ }^{5}$ \\ ${ }^{1}$ Division de Estudios de Posgrado e Investigacion, Tecnologico Nacional de México/Campus Conkal, Conkal, Yucatan, Mexico \\ 2 Division de Estudios de Posgrado e Investigacion, Tecnologico Nacional de Mexico/Campus Conkal, Conkal, Yucatan, Mexico \\ 3 Division de Estudios de Posgrado e Investigacion, Tecnológico Nacional de México/Campus Conkal, Conkal, Yucatan, Mexico \\ 4 Centro de Investigacion Cientifica de Yucatan, Merida, Yucatan, Mexico \\ 5 Division de Estudios de Posgrado e Investigacion, Conacyt-Tecnológico Nacional de México/Campus Conkal, Conkal, Yucatan, Mexico \\ Corresponding Author: Horacio Salomon Ballina-Gomez \\ Email address: horacio.bg@conkal.tecnm.mx
}

Plant-insect interactions are a determining factor for sustainable crop production. Although plants can resist or tolerate herbivorous insects to varying degrees, even with the use of pesticides, insects can reduce plant net productivity by as much as $20 \%$, so sustainable strategies for pest control with less dependence on chemicals are needed. Selecting plants with optimal resistance and photosynthetic traits can help minimize damage and maintain productivity. Here, 27 landrace accessions of lima beans, Phaseolus lunatus L., from the Yucatan Peninsula were evaluated in the field for morphological resistance traits, photosynthetic characteristics, insect damage and seed yield. Variation was found in physical leaf traits (number, area, and dry mass of leaves; trichome density, specific leaf thickness and hardness) and in physiological traits (photosynthetic rate, stomatal conductance, intercellular carbon, water-use efficiency, and transpiration). Five accessions (JMC1325, JMC1288, JMC1339, JMC1208 and JMC1264) had the lowest index for cumulative damage with the highest seed yield, although RDA analysis uncovered two accessions (JMC1339, JMC1288) with strong positive association of seed yield and the cumulative damage index with leaf production, specific leaf area (SLA) and total leaf area. Leaf traits, including SLA and total leaf area are important drivers for optimizing seed yield. This study identified 12 important morphological and physiological leaf traits for selecting landrace accessions of $P$. lunatus for high yields (regardless of damage level) to achieve sustainable, environmentally safe crop production. 


\section{Determining relevant traits for selecting landrace}

2 accessions of Phaseolus lunatus $L$. for insect

\section{3 resistance}

4 Roberto R. Ruiz-Santiago ${ }^{1}$, Horacio S. Ballina-Gómez ${ }^{1,2}$, Esaú Ruiz-Sánchez ${ }^{1}$, Jaime Martínez-

5 Castillo $^{3}$, René Garruña-Hernández ${ }^{4}$, Rubén H. Andueza-Noh ${ }^{4}$.

$6 \quad{ }^{1}$ Tecnológico Nacional de México/Campus Conkal, Conkal, Yucatán, México.

7 3 Centro de Investigación Científica de Yucatán, Mérida, Yucatán, México.

$8{ }^{4}$ Conacyt-Tecnológico Nacional de México/Campus Conkal, Conkal, Yucatán, México.

9 Corresponding Author:

10

Horacio Salomón Ballina-Gómez²

Avenida Tecnológico s/n, C.P. 97345, Conkal, Yucatán, México.

Email address: horacio.bg@conkal.tecnm.mx

\section{Abstract}

Plant-insect interactions are a determining factor for sustainable crop production. Although plants can resist or tolerate herbivorous insects to varying degrees, even with the use of pesticides, insects can reduce plant net productivity by as much as $20 \%$, so sustainable strategies for pest control with less dependence on chemicals are needed. Selecting plants with optimal resistance and photosynthetic traits can help minimize damage and maintain productivity. Here, 27 landrace accessions of lima beans, Phaseolus lunatus L., from the Yucatan Peninsula were evaluated in the field for morphological resistance traits, photosynthetic characteristics, insect damage and seed yield. Variation was found in physical leaf traits (number, area, and dry mass of leaves; trichome density, specific leaf thickness and hardness) and in physiological traits (photosynthetic rate, stomatal conductance, intercellular carbon, water-use efficiency, and transpiration). Five accessions (JMC1325, JMC1288, JMC1339, JMC1208 and JMC1264) had the lowest index for cumulative damage with the highest seed yield, although RDA analysis uncovered two accessions (JMC1339, JMC1288) with strong positive association of seed yield and the cumulative damage index with leaf production, specific leaf area (SLA) and total leaf 
28 area. Leaf traits, including SLA and total leaf area are important drivers for optimizing seed

29 yield. This study identified 12 important morphological and physiological leaf traits for selecting

30 landrace accessions of $P$. lunatus for high yields (regardless of damage level) to achieve

31 sustainable, environmentally safe crop production.

32 Introduction

33

34

35

36

37

38

39

40

41

42

43

44

45

46

47

48

49

50

51

52

53

54

55

56

In recent years, global crop productivity has been improved through the artificial selection of traits that increase yield (Lynch, 2007), but this approach has resulted in low levels of diversity, lack of expression of defense genes, and production systems that depend on high inputs of pesticides (Panda \& Khush, 1995; Lynch, 2007; Chen et al., 2016). One of the main constraints on crops is insect damage to leaves; up to $20 \%$ of the net productivity in important crops can be lost despite increased pesticide use (Oerke \& Dehne, 2004; Agrawal, 2011). Stout (2013) proposed an effective sustainable alternative: selecting plants with resistance and tolerance traits that reduce the impact of insect damage. The efficacy of such resistance traits in protecting a crop against herbivorous insects depends on studies that clarify their influence, their impact on herbivorous insects and their expression under different environmental conditions (Strauss \& Agrawal, 1999; Stinchcombe, 2002). Some accessions with larger leaves are likely to have greater vigor and tolerance to damage by herbivorous insects (Ssekandi et al., 2016). Likewise, the thickness and hardness of leaves also have an important impact on resistance. In Fabaceae species, trichomes can also contribute to resistance against defoliating insects (Oghiakhe, 1992; Veeranna \& Hussain, 1997) by hindering their movement on the plants (Tian et al., 2012; Figueiredo et al., 2013). In contrast, some plants with thinner, more fragile leaves are less preferred by insects, as in the case of Vigna radiata (L.) (Lakshminarayan et al., 2008), V. mungo (Taggar \& Gill, 2012), Gossypium hirsutum (Butter \& Vir, 1989) and Cucumis sativus (Shibuya et al., 2009).

Legumes are the second most important group in past and current agricultural systems and for human nutrition (Blair et al., 2016). According to the FAO in 2018, beans were third in importance by planted area in Mexico, with $7.9 \%$ of the total. The Yucatan Peninsula has the greatest richness of cultivated domesticated beans in all of Mexico, and varieties have high levels of genetic diversity including those of P. lunatus (Martínez-Castillo et al., 2012), which are 
57 excellent germplasm sources for improving cultivated beans. We hypothesized that landrace

58

59

60

61

62

63

64

65

66

67

68

69

70

71

72

73

74

75 76 77

accessions of broad beans (Phaseolus lunatus) have physical and physiological characteristics that confer defensive traits that may reduce the activity of herbivorous insects and optimize yields. In this context, the objective of this study was to identify accessions that were most resistant to damage caused by defoliating insects in 27 landrace accessions of lima beans $(P$. lunatus) by determining morphological, physiological and yield traits known to contribute to insect resistance such as dry mass of leaves, leaf area, specific leaf area (SLA), leaf thickness and hardness, and trichome density, improvement in photosynthetic capacity, and its impact on yield (Gong \& Zhang, 2014).

\section{Materials and Methods}

\section{Seed sources}

Seeds of 27 landraces accessions of lima beans (P. lunatus) were collected in the states of Quintana Roo, Campeche and Yucatán in the Yucatan peninsula from home gardens and rural markets. Information on the origin and genetic characterization of landraces is available in previous studies carried out by the Centro de Investigacion Cientifica de Yucatan (CICY), in Martínez-Castillo et al. (2008) and Camacho-Pérez et al. (2018) (Table 1). Seeds were tested for germination, and only those lots with germination above $85 \%$ were sown.

\section{Site conditions and crop establishment}

The field experiment was carried out in September, October, November and December of 2019 in the horticultural production area of the National Technological Institute of Mexico, Campus Conkal when the monthly mean temperature was $26.4{ }^{\circ} \mathrm{C}$, the maximum was $34.7^{\circ} \mathrm{C}$, and minimum was $17.3^{\circ} \mathrm{C}$, and the monthly mean precipitation was $100.66 \mathrm{~mm}$. The soil is a Leptosol, with $0.93 \% \mathrm{~N}$, and the total contents of $\mathrm{P}, \mathrm{K}, \mathrm{Ca}$ and $\mathrm{Mg}$ is 2.45, 3.5, 49.38 and $2.63 \mathrm{~g}$ $\mathrm{kg}^{-1}$, respectively. Seeds were sown directly every $60 \mathrm{~cm}$ in a 50-m row with a distance of 120 $\mathrm{cm}$ between each row. Approximately 100 plants per accession were obtained. The field was irrigated each day (7:00 to 9:00) with a drip irrigation strip system, and traditional agronomic management was applied for weed control; no pesticides or chemical fertilizers were applied. 
84 Plots were established using a split-plot experimental design with a completely random 85 arrangement of three subplots.

\section{Data collection}

87 At 60 days after plant emergence (DAE), morphological and physiological leaf traits of each

88

89

90

91

92

93

94

95

96 landrace accession were evaluated. We randomly selected five plants for each of three experimental subplots for each accession for a total of 15 plants. All leaves on each plant were counted, and area of each leaf was measured with an area meter (LI-3000C portable meter, LICOR, Lincoln NE, USA). The dry mass of leaves was obtained by placing fresh leaves in a drying oven at $60{ }^{\circ} \mathrm{C}$ until mass was constant. The SLA $\left(\mathrm{cm}^{2} \mathrm{~g}^{-1}\right)$ was calculated by dividing the leaf area $\left(\mathrm{cm}^{2}\right)$ by the dry mass $(\mathrm{g})$. Leaf thickness was measured with a digital micrometer (Mitutoyo model H-2780 JPN). Blade hardness $\left(\mathrm{g} \mathrm{cm}^{-2}\right)$ was measured with a portable penetrometer (AMS 59032 OSHA, USA). Trichomes were counted on several parts of the adaxial surface of the fully expanded youngest leaf using a stereoscope (OPTIKA ST-30FX IT) at $40 \times$ to calculate density (no. $\mathrm{cm}^{-2}$ ) (Widstrom et al., 1979).

An infrared gas analyzer (LI-6400 IRGA, LI-COR, Lincoln NE, USA) was used to measure gas exchange in three fully extended young leaves for each of 15 new randomly selected plants of each accession. Each leaf was measured five times for photosynthetic assimilation rate $\left(P_{\mathrm{N}}\right)$, stomatal conductance $\left(g_{\mathrm{s}}\right)$, intercellular carbon $\left(C_{\mathrm{i}}\right)$, and transpiration $(E)$. Water-use efficiency (WUE) was then calculated as assimilation rate $\left(A_{\mathrm{N}}\right)$ divided by transpiration rate $(E)$. Measurements were done between 7:00 and 10:00 when flowering had started (between 45 and 60 DAE).

\section{Leaf damage and yield}

To evaluate foliar damage by chewing insects on 15 plants randomly selected per plot at 30, 45 and 60 DAE, we used the percentage damage scale of Dirzo and Domínguez (1995): (0) leaves without herbivory, (1) 1 to $5 \%$ damage, (2) 6 to $12 \%$ damage, (3) 13 to $25 \%$ damage; (4) 26 to $50 \%$ damage and (5) above 50\% damage). At each sampling date, we also calculated a cumulative damage index for each accession by dividing the lowest damage value by the highest value for the accession (Sohrabi et al., 2016). 
112 For yield determinations, 15 plants were selected per accession, pods were harvested and beans 113 removed and oven-dried at $60^{\circ} \mathrm{C}$ until mass was constant. Beans were then weighted to obtain 114 seed yield per plant $\left(\mathrm{g} \mathrm{plant}^{-1}\right)$ for each accession.

\section{Statistical analyses}

116 We ran a one-way analysis of variance (ANOVA) to compare morphological and physiological 117 traits, damage and seed yield among the accessions; thus, we used accession as the only factor 118 (independent variable). When the data did not meet normality assumptions, data were 119 transformed as follows: continuous data with the natural logarithm, discrete numbers with square 120 root, and proportions with the arcsine of the square root. Hierarchical grouping of means tests of 121 the Scott-Knott statistic were then applied.

122 These analyses were performed with the InfoStat software (Di Rienzo et al., 2016). The most 123 important resistance and physiological tolerance traits for the accessions were identified using a 124 principal component analysis (PCA) and the arithmetic means for each accession for a variable. 125 The PCA was performed using correlation matrices and normalization of the model by the 126 varimax rotation method (Dien et al., 2005) using SPSS version 25 (IBM, Armonk, NY, USA).

127 To determine possible associations between variables, we subjected all data for physical and 128 physiological traits, seed yield and cumulative damage index for each of the 27 accessions using 129 a redundancy analysis (RDA) (Legendre \& Legendre, 1998). The RDA was chosen over a 130 canonical correspondence analysis due to the length of the gradient for the variables (Ter Braak $131 \&$ Smilauer, 2002). Gradient length was calculated using a detrended correspondence analysis 132 (DCA) (Hill 1979). The significance of the damage and yield index on the ordering of 133 morphological and physiological variables, was analyzed using a Monte Carlo random 134 permutation test (499 permutations, $p<0.05$ ) using Canoco 4.5 (Ter Braak \& Smilauer, 2002).

Results

\section{Physical traits of resistance}

137 Significant differences in the physical traits were found among the accessions (Scott-Knott $p<$ 138 0.005). The accessions with the most leaves were JMC1339, JMC1306, JMC1364, JMC1208, 
139 JMC1264, JMC1313, JMC1336, JMC1288 and JMC1348 had the fewest (Figure 1 A). JMC1339

140 had the largest leaf area, JMC1255 and JMC1348 the smallest (Figure 1 B). JMC1255,

141 RRS0002, JMC1280 JMC1348 and JMC1304 had the highest leaf dry mass; JMC1339 had the

142 lowest (Figure $1 \mathrm{C}$ ). JMC1255 had the thickest leaves, and JMC1325 accession had the thinnest

143 (Figure 1 D). JMC1339 had the highest SLA, and JMC1255, JMC1348, RRS002, JMC1280,

$144 \mathrm{JMC} 1304$ and JMC1357 had the lowest (Figure $1 \mathrm{E}$ ). The highest trichome densities were found 145 on JMC1306 and JMC1280, the lowest on JMC1208 (Figure 1 F). JMC1264, JMC1325 and 146 JMC1313 had the hardest leaves, and the rest had softer leaves (Figure. $1 \mathrm{G}$ ).

147 Physiological traits

148 The physiological variables also differed significantly among the accessions (Scott-Knott $p<$ 149 0.005). Accessions JMC1273, JMC1325, JMC1264, RRS0002, JMC1245, JMC1288, JMC1313, 150 JMC1304, JMC1280, JMC1357, JMC1270 and JMC1350 had the highest photosynthetic rate $151\left(P_{\mathrm{N}}\right), \mathrm{JMC} 1336$ and JMC1339 the lowest (Figure $\left.2 \mathrm{~A}\right)$. WUE was highest in JMC1337, $152 \mathrm{JMC1245}$, and JMC1270, and lowest in JMC1336 (Figure $2 \mathrm{~B}$ ). JMC1364 had the highest $g_{\mathrm{s}}$, for 153 overall (Figure 2 C). Transpiration was highest in JMC1273 and JMC1364 (Figure 2 D).

$154 \mathrm{JMC} 1336$ and JMC1364 had the highest $C_{\mathrm{i}}$ for overall (Figure $2 \mathrm{E}$ ).

\section{Leaf damage and yield}

156

157

158

159

160

161

162

163

164

165

166

The percentage of leaf damage differed significantly among all accessions (Scott-Knott $p<$ $0.005)$ and at DAE (Scott-Knott $p<0.005)$. The highest percentages of damage were found at 45 DAE, followed by 60 and 30 DAE. At 30 DAE, accessions JMC1271, JMC1255 and RRS0001 had the highest percentages of damage, and JMC1325, JMC1336, JMC1297, JMC1313, JMC1288, JMC1270, JMC1364, JMC1348, JMC1337, JMC1245, JMC1339, JMC1306 and JMC1264 had the lowest (Figure 3 A). For the damage index, RRS0001, JMC1271 and JMC1255 had the highest values; JMC1297, JMC1325, JMC1306, JMC1273 and JMC1264 had the lowest (Table 2). At 45 DAE, JMC1273 had the highest percentage of foliar damage; JMC1306, JMC1264 and JMC1357 had the lowest (Figure 3 B). The damage index at 45 DAE showed that JMC1255, JMC1273, JMC1280 and JMC1339 had the greatest damage; JMC1306, JMC1264, JMC1325 and RRS0002 had the lowest (Table 2). At day 60 DAE, the highest 
167 percentages of leaf damage were on JMC1348, JMC1336, JMC1339, JMC1288, JMC1327, the 168 lowest were on JMC1297, JMC1357, JMC1306, JMC1304, JMC1255 and JMC1325 (Figure 3

169 C). In addition, the damage index was notably higher for JMC1336 than for JMC1348, 170 JMC1339, JMC1288, JMC1306, JMC1264, JMC1325, JMC1297 and JMC1313, which had the 171 lowest values (Table 2). Seed yields also differed significantly among accessions (Scott-Knott $p$ $172<0.005$ ), the accessions JMC1325 and JMC1348 had the highest yield (Table 2).

\section{Variation in resistance and physiological traits}

174 In the PCA for the 12 resistance and gas-exchange traits evaluated, five main components were 175 significant with values $>1$. These components together explained $86.72 \%$ of the variation. PC1 176 explained $32.45 \%$ of the total variation in the original data, PC2 $18.32 \%$, PC3 $15.20 \%$, PC4 177 11.02\% and PC5 explained 9.72\% (Figure 4, Table 3). PC1 consisted of leaf area, SLA, number 178 of leaves and dry mass; PC2 consisted only of $P_{\mathrm{N}}$, PC3 of WUE, PC4 of $g_{\mathrm{s}}$ and $C_{\mathrm{i}}$, and PC5 was 179 formed solely by trichome density (Figure 4, Table 3).

\section{Association of resistance traits and physiology to performance}

181

182

183

184

185

186

187

188

189

190

191

192

193

The RDA showed a reduced separation of the morphological and physiological variables (eigenvalues axis $1<0.1$; cumulative variance $99.1 \%$ ), although the axes were marginally significant (axis 1: $F=2.1, p=0.054$; all axes: $F=1.06, p=0.056$ ) (Figure 5). In addition, the damage index was significantly higher (Monte Carlo test, $F=2.04, p=0.02$ ) in accessions JMC1339 and JMC1288, which had the most leaves and greatest SLA and foliar area. Although the difference in seed yield was not significant, it did tend to be higher in these accessions (Figure 5). In contrast, JMC1270, JMC1245 and JMC1254 had the least damage, but the lowest seed yield. In addition, they had the highest values of foliar biomass, for gas-exchange variables $\left(P_{\mathrm{N}}, E, g_{\mathrm{s}}, \mathrm{WUE}\right.$ and $\left.C_{\mathrm{i}}\right)$ and defense traits (hardness, thickness, and trichome density).

\section{Discussion}

The data showed a wide variation in the evaluated foliar characteristics, in line with the high diversity among the evaluated landrace accessions found by Ballesteros (1999) and MartínezCastillo et al., (2004) for P. lunatus in the Yucatan Peninsula. In the search for pest resistance 
194 among select landrace accessions, genetic variation is a key element because the wider genetic

195

196

197

198

199

200

201

202

203

204

205

206

207

208

209

210

211

212

213

214

215

216

217

218

219

220

221

222

223

224

pool increases the likelihood of finding highly resistant populations as found for Vigna umbellata resistant to Callosobruchus chinensis (L.) (Somta et al., 2008), P. vulgaris resistant to Callosobruchus chinensis (Ku-Hwan et al., 2002), and Pisum fulvum resistant to Bruchus pisorum (Clement et al., 2002). The effectiveness of species belonging to Fabaceae in resisting damage caused by pest insects is likely a function of multiple defense mechanisms ranging from morphological characteristics to physiological adaptations (Bonte et al., 2010).

When evaluating the resistance traits independently, we found distinct differences among the accessions as reported for other traits of native and cultured materials, thus allowing selection of populations with desirable defense characteristics (Maag et al., 2015; Moya-Raygoza, 2016; dos Santos et al., 2020). Although many studies have evaluated physical resistance traits, chemical defenses, and biological interaction networks in agricultural production systems, these factors can also contribute to germplasm selection and crop improvement (Chen, 2008; Mitchell et al., 2016). Some accessions with larger leaves are likely to have greater vigor and tolerance to damage by herbivorous insects (Ssekandi et al., 2016). Likewise, the thickness and hardness of leaves also have an important impact on resistance; as leaf thickness increases, some sucking insect larvae spend less time on the leaf blade (Rao, 2002; Saheb et al., 2018). To produce large, thick leaves, the plant must also have a greater photosynthetic capacity to generate the necessary photoassimilates. Furthermore, stomatal conductance and transpiration rates play a fundamental role in the WUE of plants with large leaves such as those of $P$. lunatus. Here, the accessions with outstanding physiological traits such photosynthetic assimilation also had outstanding morphological characteristics for resisting insect damage. Plants with harder leaves require greater effort by leaf-eating insects (Schofeld et al., 2011). Accession JMC1325 in our study conditions produced the hardest and thinnest leaves, so it is a good candidate for further studies on resistance to foliar damage since some plants with thinner leaves are less preferred by insects, as in the case of Vigna radiata (L.) (Lakshminarayan et al., 2008), V. mungo (Taggar \& Gill, 2012), Gossypium hirsutum (Butter \& Vir, 1989) and Cucumis sativus (Shibuya et al., 2009). Leaf hardness has been positively associated with the nutritional quality of the leaf; thus, the insects may be able to evaluate and select their food (Larcher, 2006). Therefore, the harder leaves of some accessions might not always be defensive traits, but rather provide a better food source for certain insects, making the plant more susceptible to defoliation (Schädler et al., 2007;

Peer] reviewing PDF | (2021:02:58381:3:1:NEW 20 Jul 2021) 
225 Caldwell et al., 2016). In addition, we found that for another widely studied morphological trait, 226 trichome density, accession JMC1306 has a high density. This trait and its contribution to plant 227 defense is difficult to generalize among plant species (dos Santos et al., 2020). For example, in 228 Fabaceae species, trichomes can contribute to resistance against defoliating insects (Oghiakhe, 229 1992; Veeranna \& Hussain, 1997) by hindering pest movement on the plants (Tian et al., 2012; 230 Figueiredo et al., 2013).

231 Physiological traits also varied among accessions. Groups of accessions with high values for a 232 particular trait were found, for example, for $P_{\mathrm{N}}$ with 13 accessions; for $E, C_{\mathrm{i}}$ and WUE with two; 233 and for $g_{\mathrm{s}}$ with only one variable. For $P_{\mathrm{N}}$ and $E$, the evaluated accessions had considerably high 234 levels $\left(P_{\mathrm{N}}=24 P_{\mathrm{N}}\left[\mu \mathrm{mol}\left(\mathrm{CO}_{2}\right) \mathrm{m}^{-2} \mathrm{~s}^{-1}\right]\right.$ and $E=11\left[\mathrm{mmol}\left(\mathrm{H}_{2} \mathrm{O}\right) \mathrm{m}^{-2} \mathrm{~s}^{-1}\right]$ (Ribeiro et al., (2004), 235 since values ranged from 25 to $29\left[\mu \mathrm{mol}\left(\mathrm{CO}_{2}\right) \mathrm{m}^{-2} \mathrm{~s}^{-1}\right]$ for $P_{\mathrm{N}}$ and 8 to $9\left[\mathrm{mmol}\left(\mathrm{H}_{2} \mathrm{O}\right) \mathrm{m}^{-2} \mathrm{~s}^{-1}\right]$ for $236 E$. Thus, accessions with higher $P_{\mathrm{N}}$ seem to have a greater carboxylation capacity in the 237 environmental conditions of the region, and in the case of accessions with high $E$ values, a 238 greater release of water molecules as result of large stomatal openings (Meneses-Lazo et al., 239 2018). In addition, in the case of $g_{s}$, most accessions have low values, which could be interpreted 240 as an indicator of drought tolerance (Khazaei et al., 2019), although sometimes the ability to 241 regulate $g_{\mathrm{s}}$ can be a better strategy than having low values, as found for Phaseolus vulgaris L.

242 (Rosales et al., 2012). For $C_{\mathrm{i}}$, we only found two accessions at the highest levels, which could be 243 the result of a differential photosynthetic adjustment between accessions, and in the ability to 244 regulate mitochondrial respiration such as its photorespiration, impacting the release of $\mathrm{CO}_{2}$ 245 (Lawlor \& Cornic, 2002). For WUE, accessions JMC1337, JMC1245, and JMC1270 had higher 246 values than the rest and large leaves, a desirable combination of traits for insect resistance.

247 For all traits described, both resistance and physiological, we highlighted those with the most 248 appropriate values for optimal performance, depending on the type of trait, but an accession 249 should not be selected on the basis of one variable (Capblancq et al., 2018; Vangestel et al., 250 2018). In this regard, seven accessions-JMC1339, JMC1288, JMC1264, JMC1325, JMC1208 251 and JMC1313 - had the lowest damage indices at 60 DAE. On the basis of leaf damage, they 252 could have a better resistance throughout their ontogeny (Nzungize et al., 2012), but when we 253 also consider higher seed yield, we found that five accessions-JMC1325, JMC1288, JMC1339, 254 JMC1208 and JMC1264 - were the best performers. These accessions had the highest yields $255\left(67.0 \pm 0.92\right.$ to $\left.51.9 \pm 0.92 \mathrm{~g} \mathrm{plant}^{-1}\right)$ and lowest damage indices (0.02 to 0.03$)$. However, when 
256 we analyzed with the RDA all accessions simultaneously with the morphological and

257 physiological traits and cumulative damage index during the experiment, we found that only

258 JMC1339 and JMC1288 maintained an optimum seed yield $\left(54.9 \pm 0.92\right.$ to $55.9 \pm 2.24$ g plant $\left.^{-1}\right)$,

259 despite having a high cumulative damage index. Interestingly, we found a strong positive

260 association of leaf production, SLA and leaf area with the cumulative damage index. Overall,

261 this finding may not appear to be very surprising since some plants can maintain high yields

262 while being more susceptible to damage by pests (Lale, 1998; Kimiti, 2009; Keneni et al., 2011;

263 Kipto, 2016), perhaps because plants that allocate more resources to defense will have less to 264 allocate toward growth or reproduction (Gong \& Zhang, 2014). However, we emphasize the 265 association of a higher cumulative damage index with greater leaf production, SLA and leaf area

266 because SLA has been suggested as critical driver of variation in resource availability above 267 ground (Poorter et al., 2012), which might help lima bean compensate for the resource limitation 268 caused by the lost leaf area or even maximize light capture area (high SLA) (Evans and Poorter, 269 2001; Freschet et al., 2015) through unfolding its leaves in such a way as to avoid leaf overlap 270 (Santiago and Wright, 2007).

271 Our main results revealed positive correlations between foliar resistance traits and herbivorous 272 insect damage levels but a negative correlation between these traits and yield. Nevertheless, we 273 measured only 45 individuals for each of 27 accessions in only one environment, and the genetic 274 diversity among the accessions has not been assessed. Although it is difficult to generalize the 275 strength of the resistance traits and their possible correlations with insect damage and bean yield, 276 our study highlights the importance of morphological traits such as greater leaf production, leaf 277 area and SLA in relation to increased plant productivity (McNickle \& Evans, 2018) through the 278 capture of more light energy and efficient use of available resources in plants (Maschinski \& 279 Whitham, 1989).

\section{Conclusions}

281 Our measurements and comparisons of resistance, physiological and yield traits in landrace 282 accessions of $P$. lunatus in the Yucatan Peninsula highlights the great diversity in germplasm resources. Five accessions, JMC1325, JMC1288, JMC1339, JMC1208 and JMC1264, performed 284 the best in the field in terms of seed yield and lowest cumulative damage index, even though two, JMC1339 and JMC1288, had the greatest damage. Our results found a positive correlation 
286 between high values for "resistance traits" and actual resistance to herbivorous insect damages,

287 but a negative correlation between these traits and yield. Our study identifies important

288 morphological (number of leaves, leaf area, and dry mass of leaves; trichome density, specific

289 leaf thickness and hardness) and physiological traits (photosynthetic rate, stomatal conductance,

290 intercellular carbon, water-use efficiency and transpiration) for selecting lima bean accessions

291 belonging to landrace accessions with high yields (regardless of the damage they may suffer)

292 when no agrochemicals are used, despite the limitations of our study. This is the first step toward

293 identifying resistant lines of lima beans for sustainable, safe production in the Yucatan

294 Peninsula.

295 Acknowledgments

296 The authors thank the Consejo Nacional de Ciencia y Tecnología (CONACYT) for a doctoral 297 scholarship (No. 845968) to Roberto Rafael Ruiz Santiago. This work was supported by 298 CONACYT project (no. YUC-2018-03-01-119959): “Conservación, uso sostenible, incremento 299 de la capacidad productiva y revalorización de la Milpa Maya en Yucatán”. and Tecnológico 300 Nacional de México (TECNM) project (no. 8983.20-P): "Selección de variedades locales con 301 características morfológicas y de defensa en contra de insectos herbívoros en el cultivo de 302 Phaseolus lunatus L.”. The authors thank Ángel Manuel Herrera Gorocica, Leticia Osalde 303 Navarrete and Ramon Vela Solís for their support in fieldwork.

\section{References}

305 Agrawal AA. 2011. Current trends in the evolutionary ecology of plant defence. Functional 306 Ecology 25:420-32 DOI: 10.1111/j.1365-2435.2010.01796.x

307 Ballesteros GA.1999. Contribuciones al conocimiento del frijol Lima (Phaseolus lunatus L.) en 308 América Tropical. Colegio de Posgraduados. Montecillos, Estado de México.

309 Blair MW, Wu X, Bhandari D, Zhang X, Hao J. (2016) Role of legumes for and as horticultural 310 crops in sustainable agriculture. In: Nandwani D. Organic Farming for Sustainable Agriculture. 311 Sustainable Development and Biodiversity. DOI: 10.1007/978-3-319-26803-3_9 
312 Bonte D, De Roissart A, Vandegehuchte M L, Ballhorn D J, Van Leeuwen T, de la Peña E. 313 2010. Local adaptation of aboveground herbivores towards plant phenotypes induced by soil 314 biota. Plos One 5:11174 DOI:10.1371/journal. pone.0011174

315 Butter NS, Vir BK. 1989. Morphological basis of resistance in cotton to the whitefly Bemisia 316 tabaci. Phytoparasitica 17:251-561 DOI:10.1007/BF02980754

317 Caldwell E, Read J, Sanson GD. 2016. Which leaf mechanical traits correlate with insect 318 herbivory among feeding guilds? Annals of Botany 117:349-361 DOI: 10.1093/aob/mcv178

319 Camacho-Pérez L, Martínez-Castillo J, Mijangos-Cortés JO. 2008 Genetic structure of Lima 320 bean (Phaseolus lunatus L.) landraces grown in the Mayan area. Genetic Resources and Crop 321 Evolution 65: 229-241 DOI:10.1007/s10722-017-0525-1

322 Capblancq T, Luu K, Blum Mgb, Bazin E. 2018. Evaluation of redundancy analysis to identify 323 signatures of local adaptation. Molecular Ecology Resources DOI: 10.1101/258988

324 Chen M, Huang Y, Liu G, Qin F, Yang S, Xu X. 2016. Effects of enhanced UV-B radiation on 325 morphology, physiology, biomass, leaf anatomy and ultrastructure in male and female mulberry 326 (Morus alba) saplings. Environmental and Experimental Botany 129:85-93 DOI:

327 10.1016/j.envexpbot.2016.03.006

328 Chen Y, Schmelz EA, Wäckers F, Ruberson JR. 2008 Cotton plant, Gossypium hirsutum L., 329 defense in response to nitrogen fertilization. Journal of Chemical Ecology 34:1553-1564 DOI: $33010.1007 / \mathrm{s} 10886-008-9560-\mathrm{x}$

331 Clement SL, Hardie DC, Elberson LR. 2002. Variation among accessions of Pisum fulvum for 332 resistance to pea weevil. Crop Science 42:2167-2173.

333 Di Rienzo JA, Casanoves F, Balzarini MG, Gonzalez L, Tablada M, Robledo CW. 2016 Grupo 334 InfoStat. Universidad Nacional de Córdoba. Argentina. http://www.infostat.com.ar.

335 Dien J, Beal DJ, Berg P. 2005. Optimizing principal components analysis of event-related 336 potential analysis: Matrix type, factor loading weighting, extraction, and rotations. Clinical 337 Neurophysiology 116:1808-1825. 
338 Dirzo R, Domínguez CA. 1995. Plant-herbivore interactions in Mesoamerican tropical dry forest. 339 In: Bullock S, Mooney H, Medina E, editor(s). Seasonally dry tropical forest. Cambridge 340 University Press, Cambridge 305-325.

341 dos Santos LFC, Ruiz-Sánchez E, Andueza-Noh RH, Garruña-Hernández R,

342 Latournerie-Moreno, L. Mijangos-Cortés J.O. 2020. Leaf damage by Spodoptera frugiperda J. E.

343 Smith (Lepidoptera: Noctuidae) and its relation to leaf morphological traits in maize landraces

344 and commercial cultivars. Journal of Plant Diseases and Protection 127: 103-109 DOI:

$34510.1007 / \mathrm{s} 41348-019-00276-\mathrm{y}$

346 Evans JR, Poorter H. 2001. Photosynthetic acclimation of plants to growth irradiance: the 347 relative importance of specific leaf area and nitrogen partitioning in maximizing carbon 348 gain. Plant, Cell \& Environment 24: 755-767. DOI: 10.1046/j.1365-3040.2001.00724.x

349 FAO. 2018. World food and agriculture - Statistical pocketbook. Rome. 254.

350 Figueiredo AST, Resende JTV, Morales RGF, Gonçalves APS, Da Silva PR. 2013. The role of 351 glandular and non-glandular trichomes in the negative interactions between strawberry cultivars 352 and spider mite. Arthropod-Plant Interactions. 7:53-58 DOI: 10.1007/s11829-012- 9218-z

353 Freschet GT, Swart EM, Cornelissen JHC. 2015. Integrated plant phenotypic responses to 354 contrasting above- and below-ground resources: key roles of specific leaf area and root mass 355 fraction. New Phytol 206: 1247-1260. DOI: 10.1111/nph.13352

356 Gong B, Zhang G. 2014. Interactions between plants and herbivores: A review of plant defense.

357 Ecological Society of China 34:325-336 DOI: 10.1016/j.chnaes.2013.07.010

358 González MA, Bordera S, González DH. 2015. Spatio-temporal diversity of Cryptinae

359 (Hymenoptera, Ichneumonidae) assemblages in a protected area of southeast Mexico Journal of

360 Insect Conservation 19:1153-1161. DOI: 10.1007/s10841-015-9830-1

361 Hill MO. 1979. DECORANA-A FORTRAN program for detrended correspondence analysis and 362 reciprocal averaging. Ithaca, New York: Cornell University, 1-52.

363 Keneni G, Bekele E, Imtiaz M. 2011. Breeding chickpea (Cicer arietinum [Fabaceae]) for better 364 seed quality inadvertently increased susceptibility to adzuki bean beetle (Callosobruchus 
365 chinensis [Coleoptera: Bruchidae]). International Journal of Tropical Insect Science 31: 249-261

366 DOI:10.1017/S1742758411000373

367 Khazaei H, Wach D, Pecio A, VandenbergA, Stoddard FL, Genetic analysis of photosynthesis-

368 related traits in faba bean (Vicia faba L.) for crop improvement. Plant Breeding 138:761-769

369 DOI: 10.1111/pbr.12716

370 Kimiti JM, Odee DW. Vanlauwe B. 2009. Area under grain legumes cultivation and problems

371 faced by smallholder farmers in legume production in the semi-arid eastern Kenya. Journal of

372 Sustainable Development in Africa 11:305-315.

373 Kiptoo GJ, Kinyua M, Kiplagat O, Wanjala FME, Kiptoo JJ, Cheboi JJ, Kimno SK, Rotich

374 G, Ngurwe JK. 2016. Evaluation of common bean (Phaseolus vulgaris L.) varieties for

375 resistance to bean stem Maggot (Ophiomyia spp.) in Kenya. American Journal of Experimental

376 Agriculture12 1-7.

377 Ku-Hwan L, Seung-Keun J, Sang-II P, Beom-Heon S, Yong-Gu C, Hong-Sig K, 2002.

378 Agronomic characteristics of resistant mungbean to Callosbruchus chinensis. Journal of 379 Agricultural Science 19: 41-52.

380 Lakshminarayan S, Singh PS, Mishra DS. 2008. Relationship between whitefly population,

381 YMV disease and morphological parameters of green gram germplasm. Environment and

382 Ecology 26: 978-982.

383 Lale NES, Kolo AA. 1998. Susceptibility of eight genetically improved local cultivars of cowpea

384 to Callosobruchus maculatus F. (Coleoptera: Bruchidae) in Nigeria. International Journal of Pest

385 Management 44: 25-27 DOI: 10.1080/096708798228482

386 Larcher W. Ecofisiologia vegetal. RiMa, São Carlo. 2006;(5)525-550.

387 Lawlor DW, Cornic G. 2002. Photosynthetic carbon assimilation and associated metabolism in 388 relation to water deficits in higher plants. Plant, Cell and Environment. 25:275-294 DOI:

389 10.1046/j.0016-8025.2001.00814.x

390 Legendre P, Legendre L. 1998. Numerical ecology. Ed. Amsterdam Elsevier, The Netherland, 391380. 
392 Lynch JP. 2007. Roots of the second green revolution. Australian Journal of Botany, 55:493393 512. DOI: $10.1071 / \mathrm{bt} 06118$

394 Maag D, Erb M, Bernal JS, Wolfender JL, Turlings TCJ, Glauser G. 2015. Maize domestication 395 and anti-herbivore defences: leaf-specifc dynamics during early ontogeny of maize and its wild 396 ancestors. PLOS ONE. 8:e135722 DOI: 10.1371/journ al.pone.0135722

397 Martinez-Castillo J, Camacho-Perez L, Coello-Coello J, Andueza-Noh R. 2012. Wholesale 398 replacement of Lima bean (Phaseolus lunatus L.) landraces over the last 30 years in northeastern 399 Campeche, Mexico. Genetic Resources and Crop Evolution, 59:191-204 DOI: 10.1007/s10722$400 \quad 011-9675-8$

401 Martínez-Castillo J, Colunga-García M, P. \& Zizumbo-Villarreal D. 2008. Genetic erosion 402 and in situ conservation of Lima bean (Phaseolus lunatus L.) landraces in its Mesoamerican 403 diversity center. Genetic Resources and Crop Evolution 55: 1065-1077 DOI: 10.1007/s10722$404 \quad 008-9314-1$

405 Martínez-Castillo J, Zizumbo-Villarreal D, Perales-Rivera H, Colunga-García M.

406 2004. Intraspecific diversity and morpho-phenological variation in Phaseolus lunatus L. from the 407 Yucatan Peninsula, Mexico. Economic Botany, 58: 354-380 DOI: 10.1663/0013408 0001(2004)058[0354:IDAMVI]2.0.CO;2

409 Maschinski J, Whitham TG. 1989. The Continuum of Plant Responses to Herbivory: The 410 Influence of Plant Association, Nutrient Availability, and Timing. The American Naturalist, 411 134:1-19 DOI: 10.1086/284962

412 McNickle GG, Evans WD. 2018. Toleration games: compensatory growth by plants in response 413 to enemy attack is an evolutionarily stable strategy. AoB Plants. 10:1-14. DOI:

414 10.1093/aobpla/ply035

415 Meneses-Lazo RE, Garruña-Hernández R, Latournerie-Moreno L, Andrade-Torres JL, Pérez416 Gutiérrez A. 2018. Phenological and physiological characterization of experimental habanero 417 pepper varieties with high agronomic potential. Revista Fitotecnia Mexicana 41:67-74. 
418 Mitchell C, Brennan RM, Graham J, Karley AJ. 2016. Plant defense against herbivorous pests:

419 exploiting resistance and tolerance traits for sustainable crop protection. Frontiers in Plant 420 Science 7:1132 DOI: 10.3389/fpls.2016.01132,

421 Moya-Raygoza G. 2016. Early development of leaf trichomes is associated with decreased 422 damage in teosinte, compared with maize, by Spodoptera frugiperda (Lepidoptera: Noctuidae). 423 Annals of the Entomological Society of America 109:737-743 DOI: 10.1093/aesa/saw049

424 Nzungize JR, Lyumugabe F, Busogoro JP, Baudoin J-P. 2012. Pythium root rot of common 425 bean: Biology and control methods. A review. Biotechnology. Agronomy, Society and 426 Environment 16:405-413.

427 Oerke EC, Dehne HW. 2004. Safeguarding production-losses in major crops and the role of crop 428 protection Crop Protection 23:275-285 DOI: 10.1016/j.cropro.2003.10.001

429 Oghiakhe LEN, Jackai L, Makanjuola WA. 1992. A rapid visual field screening technique for 430 resistance of cowpea (Vigna unguiculata) to the legume pod borer, Maruca testulalis 431 (Lepidoptera: Pyralidae). Bulletin of Entomological Research 82: 507-512. DOI: $43210.1017 / \mathrm{S} 0007485300042589$

433 Panda N, Khush GS. 1995. Host Plant Resistance to Insects. CAB International in Association 434 with International Rice Research Institute (IRRI).

435 Poorter H, Niklas KJ, Reich PB, Oleksyn J, Poot P, Mommer L. 2012. Biomass allocation to 436 leaves, stems and roots: meta-analyses of interspecific variation and environmental control. New 437 Phytologist 193: 30-50. DOI: 10.1111/j.1469-8137.2011.03952.x

438 Rao RVS. 2002. Method of screening for resistance to leaf miner, Aproaerema modicella 439 (Deventer) under greenhouse conditions. Annals of Plant Protection Sciences 10:38-41.

440 Ribeiro RV, dos Santos MG, Souza GM, Machado EC, de Oliveira RF, Angelocci LR, Pimentel 441 C. 2004. Environmental effects on photosynthetic capacity of bean genotypes. Pesquisa 442 Agropecuária Brasileira 39:615-623 DOI: 10.1590/S0100-204X2004000700001

443 Rosales MA, Ocampo E, Rodríguez-Valentín R, Olvera-Carrillo Y, Acosta-Gallegos J, 444 Covarrubias AA. 2012. Physiological analysis of common bean (Phaseolus vulgaris L.) cultivars 
445 uncovers characteristics related to terminal drought resistance. Plant Physiology and 446 Biochemistry 56:24-34 DOI: 10.1016/j.plaphy.2012.04.007

447 Saheb YP, Hari-Prasad KV, Swarajya KL, Rani JS. 2018. Mechanisms of resistance in 448 groundnut genotypes against leaf bud borer, Anarsia ephippias (Meyrick). Journal of 449 Entomology and Zoology Studies 6: 694-705

450 Santiago LS, Wright SJ. 2007. Leaf functional traits of tropical forest plants in relation to growth 451 form. Functional Ecology 21: 19-27. DOI: 10.1111/j.1365-2435.2006.01218.x

452 Schädler M, Roeder M, Brandl R, Matthies D. 2007. Interacting effects of elevated $\mathrm{CO}_{2}$, nutrient 453 availability and plant species on a generalist invertebrate herbivore. Global Change Biology 454 13:1005-1015 DOI: 10.1111/j.1365-2486.2007.01319.x

455 Schofeld RMS, Emmett KD, Niedbala JC, Nesson MH. 2011. Leafcutter ants with worn 456 mandibles cut half as fast, spend twice the energy, and tend to carry instead of cut. Behavioral 457 Ecology and Sociobiology 65:969-982. DOI:10.1007/s00265-010-1098-6

458 Shibuya T, Hirai N, Sakamoto Y, Komuro J. 2009. Effects of morphological characteristics of 459 Cucumis sativus seedlings grown at different vapor pressure deficits on initial colonization of 460 Bemisia tabaci (Hemiptera: Aleyrodidae). Journal of Economic Entomology 102: 2265-2267 461 DOI: $10.1603 / 029.102 .0631$

462 Sohrabi F, Nooryazdan HR, Gharati. 2017. plant resistance to the moth Tuta absoluta (Meyrick) 463 (Lepidoptera:Gelechiidae) in tomato cultivars. Neotropical Entomology 46:203-209 DOI: 464 10.1007/s13744-016-0441-7

465 Somta P, Kaga A, Tomooka N, Isemura T, Vaughan DA, Srivines P. 2008. Mapping of 466 quantitative trait loci for a new source of resistance to bruchids in the wild species Vigna 467 nepalens Tateishi \& Maxted (Vigna subgenus Ceratotropis). Theoretical and Applied Genetics 468 117: 621-628 DOI: 10.1007/s00122-008-0806-3

469 Ssekandi JW, Mulumba J, Colangelo P, Nankya R, Fadda C, Karungi J, Otim M, De Santis P, 470 Jarvis DI. 2016. The use of common bean (Phaseolus vulgaris) traditional varieties and their 471 mixtures with commercial varieties to manage bean fly (Ophiomyia spp.) infestations in Uganda. 472 Journal of Pest Science 89:45-57 DOI: 10.1007/s10340-015-0678-7 
473 Stinchcombe J. 2002. Can tolerance traits impose selection on herbivores? Evolutionary Ecology 474 16:595-602. DOI: 10.1023/A:1021617418037

475 Stout MJ. 2013. Re-evaluating the conceptual framework for applied research on host-plant 476 resistance. Insect Science, 20:263-272. DOI: 10.1111/1744-7917.12011

477 Strauss SY, Agrawal AA. 1999. The ecology and evolution of plant tolerance to herbivory.

478 Trends in Ecology \& Evolution 14: 179-185. DOI: 10.1016/s0169- 5347(98)01576-6

479 Taggar GK, Gill RS. 2012. Preference of whitefly, Bemisia tabaci, towards black gram 480 genotypes: Role of morphological leaf characteristics. Phytoparasitica 40: 461-474 DOI:

$481 \quad 10.1007 / \mathrm{s} 12600-012-0247-\mathrm{z}$

482 Ter Braak CJF, Smilauer P. 2002. CANOCO Reference Manual and CanoDraw for Windows 483 User'Guide: Software for Canonical Community Ordination (version 4.5). Microcomputer 484 Power, Ithaca, New York, USA. 500 p.

485 Tian D, Tooker J, Peiffer M, Chung SH, Felton GW. 2012. Role of trichomes in defense against 486 herbivores: comparison of herbivore response to woolly and hairless trichome mutants in tomato 487 (Solanum lycopersicum). Planta 236:1053-1066 DOI: 10.1007/s00425-012-1651-9

488 Vangestel C, Andrew JE, Wegrzyn JL, St. Clair JB, Neale DB. 2018. Linking Phenotype, 489 Genotype and Environment to Unravel Genetic Components Underlying Cold Hardiness in 490 Coastal Douglas-Fir (Pseudotsuga Menziesii Var. Menziesii). Tree Genetics \& Genomes 14:10 491 DOI: $10.1007 / \mathrm{s} 11295-017-1225-\mathrm{X}$

492 Veeranna R, Hussain M. 1997. Trichomes as physical barriers for cowpea podborer, Maruca 493 testulalis (Geyer) (Lepidoptera: Pyralidae). Insect Environment 3:1-15.

494 Widstrom NW, McMillian WW, Wiseman BR. 1979. Ovipositional preference of the corn 495 earworm and the development of trichomes on two exotic corn selections. Environmental 496 Entomology 8:833-839 DOI: 10.1093/ee/8.5.833 


\section{Figure 1}

Means $( \pm S D)$ at 60 days after emergence for leaf resistance traits of 27 Phaseolus Iunatus landrace accessions from southeastern Mexico.

Different letters above histobars denote a significant difference among accessions (ScottKnott, $p<0.05)$. (A) number of leaves, (B) leaf area, (C) dry mass of leaves, (D) thickness, (E) specific leaf area, $(F)$ number of trichomes, $(G)$ hardness. Accession codes on $x$-axis: $1=$ RRS0001, 2 = JMC1271, $3=$ JMC1280, $4=$ RRS0002, $5=$ JMC1255, $6=$ JMC1304, $7=$ JMC1240, 8 = JMC1350, $9=$ JMC1254, $10=$ JMC1327, $11=$ JMC1273, $12=$ JMC1357, $13=$ JMC1345, $14=$ JMC1270, 15 = JMC1337, $16=$ JMC1245, $17=$ JMC1208, $18=$ JMC1348, $19=$ JMC1339, $20=$ JMC1288, $21=$ JMC1306, $22=$ JMC1264, $23=$ JMC1325, $24=$ JMC1297, $25=$ JMC1313, 26 = JMC1336, 27 = JMC1364. Days after emergence (DAE), specific leaf area (SLA). 


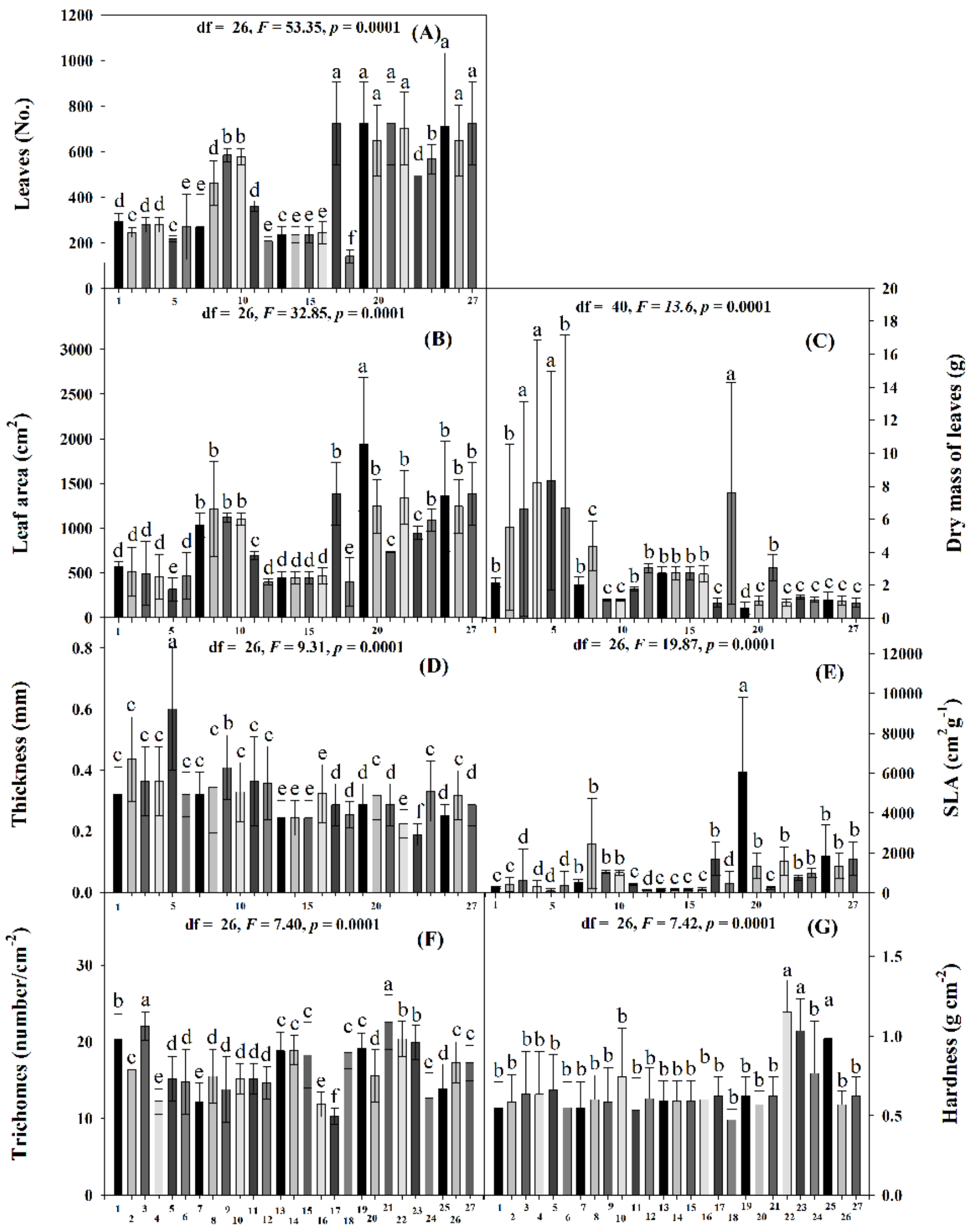




\section{Figure 2}

Means $( \pm \mathrm{SD})$ at 60 days after emergence for physiological tolerance traits of 27 Phaseolus lunatus landraces accessions from southeastern Mexico.

Different letters above histobars denote a significant difference among accessions at 60 DAE (Scott-Knott, $p<0.05)$. (A) photosynthesis assimilation rate $\left(P_{N}\right)$, (B) water-use efficiency (WUE), (C) stomatal conductance $\left(g_{s}\right),(D)$ transpiration $(E),(E)$ intercellular carbon $\left(C_{i}\right)$. Accession codes on $x$-axis: $1=$ RRS0001, $2=J M C 1271,3=J M C 1280,4=$ RRS0002, $5=$ JMC1255, 6 = JMC1304, 7 = JMC1240, $8=$ JMC1350, $9=$ JMC1254, $10=$ JMC1327, $11=$ JMC1273, $12=$ JMC1357, $13=$ JMC1345, $14=$ JMC1270, $15=$ JMC1337, $16=$ JMC1245, $17=$ JMC1208, $18=$ JMC1348, $19=$ JMC1339, $20=$ JMC1288, $21=$ JMC1306, $22=$ JMC1264, $23=$ JMC1325, 24 = JMC1297, 25 = JMC1313, 26 = JMC1336, 27 = JMC1364. 


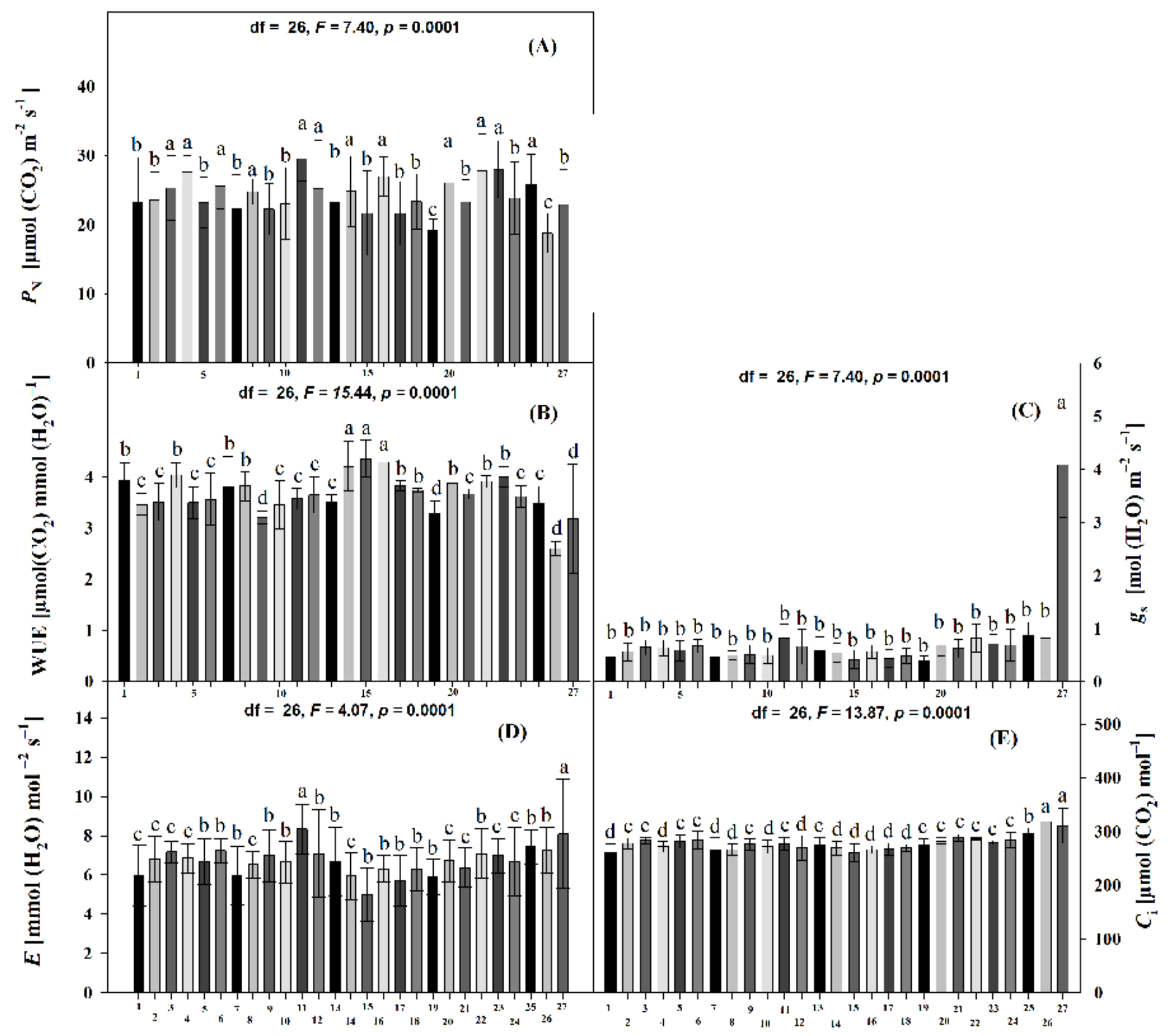


Figure 3

Mean ( \pm SD) leaf damage caused by herbivorous insects at three ages of 27 Phaseolus lunatus landrace accessions from southeastern Mexico.

Different letters above histobars denote a significant difference among accessions at (A) 30, (B) 45 and (C) 60 days after emergence (DAE) (Scott-Knott, $p<0.05$ ). 


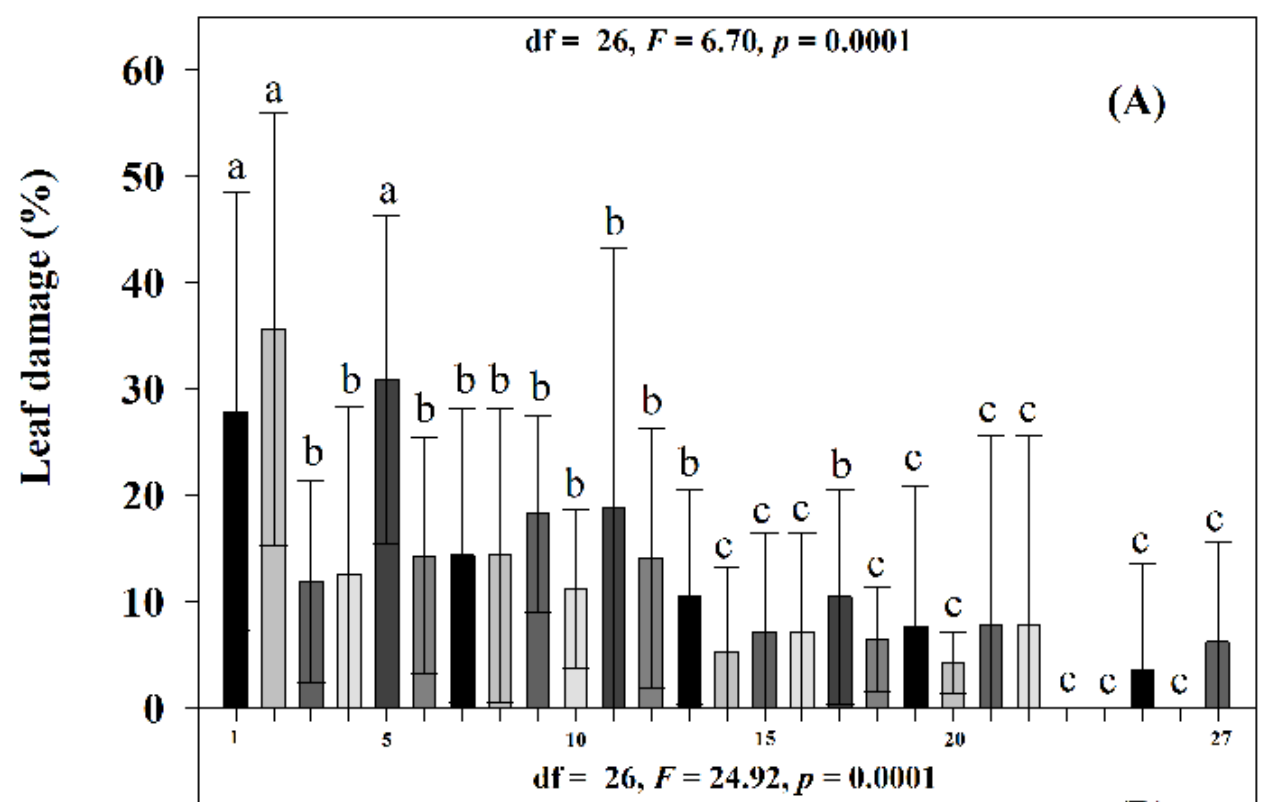

(B)

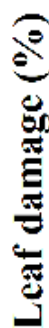

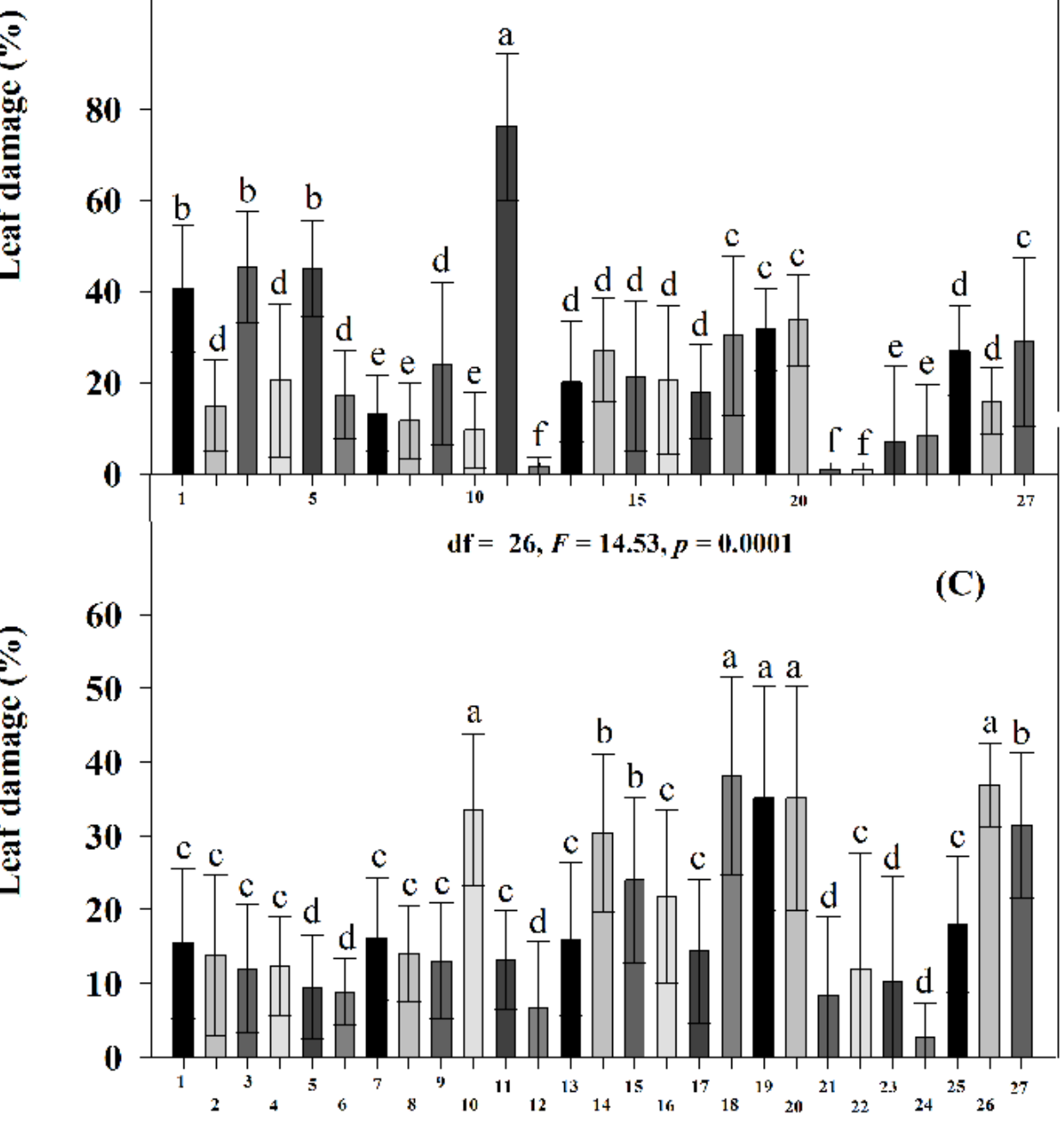




\section{Figure 4}

Biplot of principal component analysis of 27 Phaseolus lunatus landrace accessions from southeastern Mexico based on 12 morphological and physiological leaf traits.

(A) PC1 and PC2, (B) PC2 and PC3. Morphological traits: trichomes (Tr), thickness (Th), hardness $(\mathrm{Ha})$, dry mass of leaves (Dm). Physiological traits: photosynthesis assimilation rate $\left(P_{\mathrm{N}}\right)$, water-use efficiency (WUE), stomatal conductance $\left(g_{\mathrm{s}}\right)$, transpiration $(E)$, intercellular carbon $\left(C_{i}\right)$. 

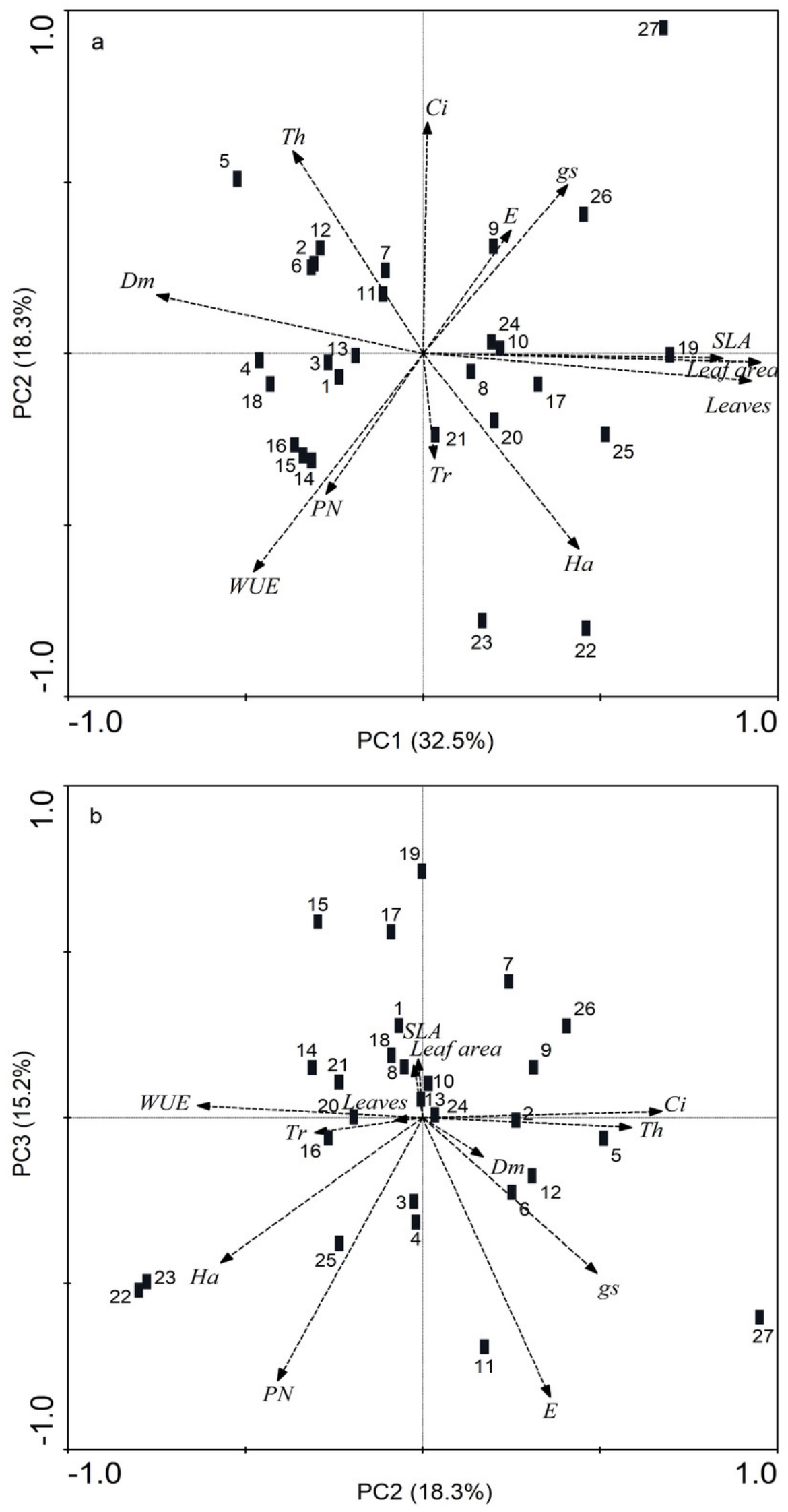

PeerJ reviewing PDF | (2021:02:58381:3:1:NEW 20 Jul 2021) 


\section{Figure 5}

Redundancy analysis showing the ordination of morphological and physiological leaf traits associated with the cumulativedamage index and seed yield of 27 landraces accessions of Phaseolus lunatus from southeastern Mexico.

Accessions: $1=$ RRS0001, $2=$ JMC1271, $3=$ JMC1280, $4=$ RRS0002, $5=\mathrm{JMC1255}, 6=$ JMC1304, $7=$ JMC1240, $8=$ JMC1350, $9=$ JMC1254, $10=$ JMC1327, $11=J M C 1273,12=$ JMC1357, $13=$ JMC1345, $14=$ JMC1270, $15=$ JMC1337, $16=$ JMC1245, $17=$ JMC1208, $18=$ JMC1348, $19=$ JMC1339, $20=$ JMC1288, $21=$ JMC1306, $22=$ JMC1264, $23=$ JMC1325, $24=$ JMC1297, 25 = JMC1313, 26 = JMC1336, 27 = JMC1364. Morphological traits: trichomes (Tr), thickness (Th), hardness (Ha), dry mass of leaves (Dm). Physiological traits: photosynthesis assimilation rate $\left(P_{N}\right)$, water-use efficiency (WUE), stomatal conductance $\left(g_{\mathrm{s}}\right)$, transpiration $(E)$, intercellular carbon $\left(C_{\mathrm{i}}\right)$. 


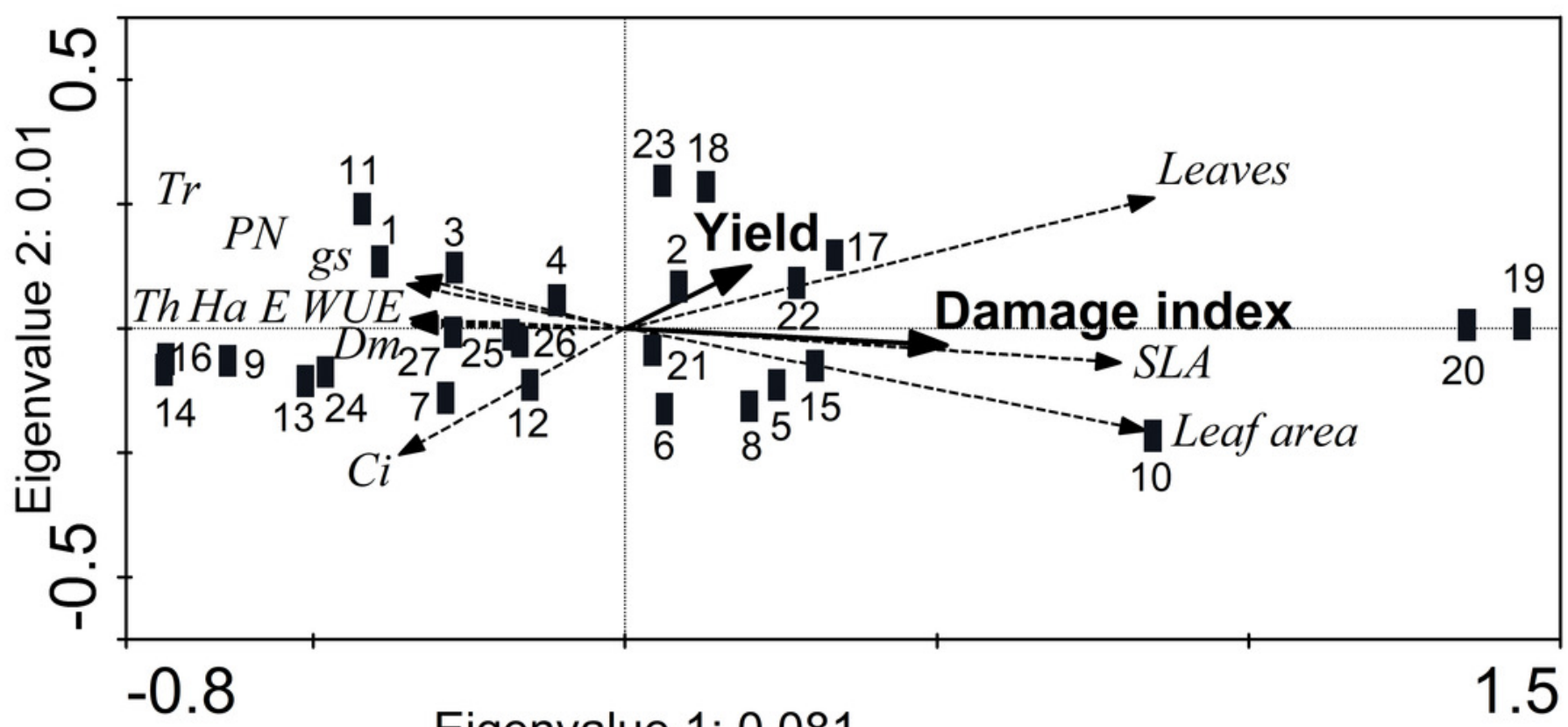

Eigenvalue 1: 0.081 


\section{Table $\mathbf{1}$ (on next page)}

Origin of landrace accessions of lima bean ( $P$. lunatus) evaluated in this study. 


\begin{tabular}{|c|c|c|c|c|c|c|c|}
\hline $\begin{array}{c}\text { Accesion } \\
\text { Code }\end{array}$ & Accession & Species & Collector & State & Municipality & Coordinate & Local name \\
\hline 1 & RRS0001 & Phaseolus lunatus & Roberto Ruiz & Yucatán & Izamal & -- & -- \\
\hline 2 & $\mathrm{JMC} 1271$ & Phaseolus lunatus & Jaime Martínez & Quintana Roo & Tulum & $87^{\circ} 46^{\prime} 16.55^{\prime \prime}$ & Putsicasutsuy \\
\hline 3 & $\mathrm{JMC} 1280$ & Phaseolus lunatus & Jaime Martínez & Quintana Roo & Felipe C. Puerto & $88^{\circ} 02^{\prime} 43^{\prime \prime}$ & Mulición \\
\hline 4 & RRS0002 & Phaseolus lunatus & Roberto Ruiz & Yucatán & Izamal & -- & -- \\
\hline 5 & $\mathrm{JMC} 1255$ & Phaseolus lunatus & Jaime Martínez & Campeche & Calkiní & $90^{\circ} 03^{\prime} 03^{\prime \prime}$ & Mulición \\
\hline 6 & JMC1304 & Phaseolus lunatus & Felix Dzul Tejero & Campeche & Calkiní & $90^{\circ} 03^{\prime} 03^{\prime \prime}$ & Mulición \\
\hline 7 & $\mathrm{JMC} 1240$ & Phaseolus lunatus & Jaime Martínez & Yucatán & Peto & $89^{\circ} 24^{\prime} 00^{\prime \prime}$ & Putsicasutsuy \\
\hline 8 & JMC1350 & Phaseolus lunatus & Jaime Martínez & Campeche & Hopelchén & $89^{\circ} 44^{\prime} 51.98^{\prime \prime}$ & X-Nuk ib \\
\hline 9 & $\mathrm{JMC1254}$ & Phaseolus lunatus & Jaime Martínez & Yucatán & Tahdziú & $89^{\circ} 30^{\prime}$ & Putsicasutsuy \\
\hline 10 & JMC1327 & Phaseolus lunatus & Jaime Martínez & Campeche & Hecelchakán & $89^{\circ} 58^{\prime} 14.48^{\prime \prime}$ & Mulición \\
\hline 11 & $\mathrm{JMC1273}$ & Phaseolus lunatus & Jaime Martínez & Campeche & Hopelchén & $89^{\circ} 35.57^{\prime}$ & Putsicasutsuy \\
\hline 12 & JMC1357 & Phaseolus lunatus & Jaime Martínez & Campeche & Calkiní & $89^{\circ} 53^{\prime} 90^{\prime \prime}$ & Mejen ib \\
\hline 13 & JMC1345 & Phaseolus lunatus & Jaime Martínez & Yucatán & Tixmehuac & $89^{\circ} 06^{\prime} 31.43^{\prime \prime}$ & Mulición \\
\hline 14 & $\mathrm{JMC} 1270$ & Phaseolus lunatus & Jaime Martínez & Yucatán & Tixmehuac & $89^{\circ} 6^{\prime} 56.16^{\prime \prime}$ & Chak ib \\
\hline 15 & JMC1337 & Phaseolus lunatus & Jaime Martínez & Campeche & Hopelchén & $89^{\circ} 11^{\prime} 30^{\prime \prime}$ & Mulición \\
\hline 16 & $\mathrm{JMC} 1245$ & Phaseolus lunatus & Felix Dzul Tejero & Campeche & Calkiní & $89^{\circ} 53^{\prime} 90^{\prime \prime}$ & Putsicasutsuy \\
\hline 17 & $\mathrm{JMC} 1208$ & Phaseolus lunatus & Jaime Martínez & Yucatán & Chankom & $88^{\circ} 30^{\prime} 48.00^{\prime \prime}$ & Sac ib \\
\hline 18 & $\mathrm{JMC} 1348$ & Phaseolus lunatus & Jaime Martínez & Yucatán & Peto & $89^{\circ} 24^{\prime} 00^{\prime \prime}$ & Sak X-nuk ib \\
\hline 19 & JMC1339 & Phaseolus lunatus & Jaime Martínez & Yucatán & Yaxcabá & $88^{\circ} 49^{\prime} 39.69^{\prime \prime}$ & Sac ib \\
\hline 20 & JMC1288 & Phaseolus lunatus & Felix Dzul Tejero & Yucatán & Tekax & $89^{\circ} 29^{\prime} 18^{\prime \prime}$ & Box ib \\
\hline 21 & $\mathrm{JMC} 1306$ & Phaseolus lunatus & Jaime Martínez & Yucatán & Tzucacab & $89^{\circ} 57^{\prime} 35^{\prime \prime}$ & Mulición \\
\hline 22 & JMC1264 & Phaseolus lunatus & Jaime Martínez & Yucatán & Yaxcabá & $88^{\circ} 49^{\prime} 39.69^{\prime \prime}$ & Chak ib \\
\hline 23 & JMC1325 & Phaseolus lunatus & Jaime Martínez & Yucatán & Tekax & $89^{\circ} 17^{\prime} 16^{\prime \prime}$ & Mejen ib \\
\hline 24 & JMC1297 & Phaseolus lunatus & Felix Dzul Tejero & Yucatán & Tixmehuac & $89^{\circ} 6^{\prime} 56.16^{\prime \prime}$ & Sac ib \\
\hline 25 & $\mathrm{JMC} 1313$ & Phaseolus lunatus & Jaime Martínez & Yucatán & Tekax & $89^{\circ} 12^{\prime} 00^{\prime \prime}$ & Sacmejen \\
\hline 26 & JMC1336 & Phaseolus lunatus & Jaime Martínez & Yucatán & Tekax & $89^{\circ} 17^{\prime} 16^{\prime \prime}$ & Sacmejen \\
\hline 27 & JMC1364 & Phaseolus lunatus & Jaime Martínez & Yucatán & Tekom & $88^{\circ} 27^{\prime} 17^{\prime \prime}$ & Sac ib \\
\hline
\end{tabular}




\section{Table 2 (on next page)}

Estimates of cumulative damage index at three growth ages (30, 45 and 60 days after emergence; DAE) and of seed yield at $60 \mathrm{DAE}$ for lima bean (P. lunatus).

The index was calculated by dividing the lowest recorded number by the highest recorded number for each accession, at 3045 y 60 DAE (days after emergence). For seed yield, different letters within a column denote a significant difference among accessions within the each DAE (Scott-Knott, $p<0.05)$. Means $( \pm S D)$. 
1

\begin{tabular}{cllllll}
\hline Accession code & Accessions & $\begin{array}{l}\text { Damage index } \\
\text { 30 DAE }\end{array}$ & $\begin{array}{l}\text { Damage index } \\
\text { 45 DAE }\end{array}$ & $\begin{array}{l}\text { Damage index } \\
\text { 60 DAE }\end{array}$ & $\begin{array}{l}\text { Seed yield } \\
\text { (g plant } \mathbf{t}^{-1} \text { ) }\end{array}$ \\
\hline 1 & RRS0001 & 0.14 & 0.24 & 0.14 & $53.6 \pm 0.62$ & $\mathrm{c}$ \\
2 & JMC1271 & 0.11 & 0.03 & 0.11 & $49.7 \pm 0.93$ & $\mathrm{c}$ \\
3 & JMC1280 & 0.03 & 0.38 & 0.09 & $53.6 \pm 0.62$ & $\mathrm{c}$ \\
4 & RRS0002 & 0.02 & 0.02 & 0.21 & $49.4 \pm 0.74$ & $\mathrm{~d}$ \\
5 & JMC1255 & 0.14 & 0.42 & 0.04 & $38.5 \pm 0.61$ & $\mathrm{~d}$ \\
6 & JMC1304 & 0.07 & 0.07 & 0.18 & $33.0 \pm 0.75$ & $\mathrm{e}$ \\
7 & JMC1240 & 0.06 & 0.11 & 0.23 & $28.1 \pm 0.92$ & $\mathrm{e}$ \\
8 & JMC1350 & 0.06 & 0.04 & 0.24 & $34.5 \pm 0.77$ & $\mathrm{e}$ \\
9 & JMC1254 & 0.03 & 0.09 & 0.11 & $31.3 \pm 0.92$ & $\mathrm{e}$ \\
10 & JMC1327 & 0.04 & 0.03 & 0.21 & $34.9 \pm 0.74$ & $\mathrm{e}$ \\
11 & JMC1273 & 0.01 & 0.42 & 0.21 & $58.8 \pm 1.69$ & $\mathrm{~b}$ \\
12 & JMC1357 & 0.02 & 0.11 & 0.03 & $35.0 \pm 0.74$ & $\mathrm{e}$ \\
13 & JMC1345 & 0.03 & 0.14 & 0.03 & $32.8 \pm 0.61$ & $\mathrm{e}$ \\
14 & JMC1270 & 0.03 & 0.22 & 0.23 & $29.0 \pm 0.92$ & $\mathrm{e}$ \\
15 & JMC1337 & 0.03 & 0.08 & 0.25 & $38.4 \pm 0.92$ & $\mathrm{~d}$ \\
16 & JMC1245 & 0.03 & 0.08 & 0.07 & $30.8 \pm 0.84$ & $\mathrm{e}$ \\
17 & JMC1208 & 0.03 & 0.16 & 0.03 & $52.4 \pm 0.01$ & $\mathrm{~b}$ \\
18 & JMC1348 & 0.05 & 0.05 & 0.18 & $66.6 \pm 0.92$ & $\mathrm{a}$ \\
19 & JMC1339 & 0.02 & 0.33 & 0.02 & $54.9 \pm 0.92$ & $\mathrm{c}$ \\
20 & JMC1288 & 0.09 & 0.34 & 0.02 & $55.9 \pm 2.24$ & $\mathrm{c}$ \\
21 & JMC1306 & 0.01 & 0.00 & 0.03 & $42.4 \pm 0.43$ & $\mathrm{~d}$ \\
22 & JMC1264 & 0.01 & 0.00 & 0.02 & $51.9 \pm 0.92$ & $\mathrm{c}$ \\
23 & JMC1325 & 0.00 & 0.02 & 0.02 & $67.0 \pm 0.92$ & $\mathrm{a}$ \\
24 & JMC1297 & 0.00 & 0.02 & 0.06 & $30.8 \pm 0.92$ & $\mathrm{e}$ \\
25 & JMC1313 & 0.02 & 0.20 & 0.03 & $39.5 \pm 0.92$ & $\mathrm{~d}$ \\
26 & JMC1336 & 0.00 & 0.04 & 0.59 & $42.1 \pm 0.74$ & $\mathrm{~d}$ \\
27 & JMC1364 & 0.03 & 0.10 & 0.27 & $42.9 \pm 0.61$ & $\mathrm{~d}$ \\
\hline
\end{tabular}

2 


\section{Table 3 (on next page)}

Variance explained in PCA by five principal components derived from 12 leaf traits of lima bean ( $P$. lunatus) and contributions of the original variables to each component.

Specific leaf area (SLA), photosynthesis assimilation rate $\left(P_{\mathrm{N}}\right)$, stomatal conductance $\left(g_{\mathrm{s}}\right)$, intercellular carbon $\left(C_{i}\right)$, water-use efficiency (WUE), transpiration $(E)$, days after emergence (DAE). 
1

\begin{tabular}{|c|c|c|c|c|c|}
\hline \multirow[b]{2}{*}{ Axes } & \multicolumn{5}{|c|}{ Principal component axes } \\
\hline & PC1 & PC2 & PC3 & PC4 & PC5 \\
\hline Eigenvalue & 3.895 & 2.199 & 1.825 & 1.323 & 1.167 \\
\hline Explained proportion of variation (\%) & 32.456 & 18.322 & 15.206 & 11.026 & 9.722 \\
\hline Cumulative proportion of variation (\%) & 32.456 & 50.778 & 65.984 & 77.010 & 86.732 \\
\hline Trait & \multicolumn{5}{|c|}{ Correlation matrix } \\
\hline Leaf area $\left(\mathrm{cm}^{2}\right)$ & 0.974 & -0.053 & 0.093 & 0.033 & -0.056 \\
\hline Dry mass $(\mathrm{g})$ & -0.776 & -0.011 & 0.267 & -0.221 & -0.042 \\
\hline $\operatorname{SLA}\left(\mathrm{cm}^{2} \mathrm{~g}^{-1}\right)$ & 0.867 & -0.085 & 0.161 & -0.06 & -0.036 \\
\hline Trichomes $\left(\mathrm{cm}^{2}\right)$ & -0.072 & -0.023 & 0.023 & -0.078 & 0.961 \\
\hline Hardness $\left(\mathrm{g} \mathrm{cm}^{-2}\right)$ & 0.454 & 0.656 & -0.129 & -0.18 & 0.182 \\
\hline Thickness (mm) & -0.389 & -0.162 & 0.62 & -0.123 & -0.486 \\
\hline Number of leaves & 0.914 & 0.092 & 0.162 & 0.025 & 0.086 \\
\hline$P_{\mathrm{N}}\left[\mu \mathrm{mol}\left(\mathrm{CO}_{2}\right) \mathrm{m}^{-2} \mathrm{~s}^{-1}\right]$ & -0.283 & 0.911 & -0.14 & -0.042 & -0.097 \\
\hline$g_{\mathrm{s}}\left[\mathrm{mol}\left(\mathrm{H}_{2} \mathrm{O}\right) \mathrm{m}^{-2} \mathrm{~s}^{-1}\right]$ & 0.207 & 0.184 & 0.248 & 0.846 & 0.146 \\
\hline$C_{\mathrm{i}}\left[\mu \mathrm{mol}\left(\mathrm{CO}_{2}\right) \mathrm{mol}^{-1}\right]$ & -0.091 & -0.291 & -0.044 & 0.87 & -0.24 \\
\hline WUE $\left[\mu \mathrm{mol}\left(\mathrm{CO}_{2}\right) \mathrm{mmol}\left(\mathrm{H}_{2} \mathrm{O}\right)^{-1}\right]$ & -0.333 & 0.248 & -0.838 & -0.157 & -0.107 \\
\hline$E\left[\mathrm{mmol}\left(\mathrm{CO}_{2}\right) \mathrm{mol}\left(\mathrm{H}_{2} \mathrm{O}\right)^{-1}\right]$ & 0.058 & 0.612 & 0.667 & 0.349 & 0.017 \\
\hline
\end{tabular}

2 